\title{
DESCRIPTION OF A NEW SPECIES AND RECORDS OF TWO KNOWN SPECIES OF NEOSTROMBOCEROS ROHWER FROM INDIA (HYMENOPTERA: SYMPHYTA: TENTHREDINIDAE: SELANDRIINAE)
}

\author{
Malkiat S. Saini, Tajinder P. Saini and V. Vasu \\ Department of Zoology, Punjabi University, Patiala, Punjab 147002, India.
}

\begin{abstract}
Two species i.e. $N$. rugifrons Malaise and $N$. tonkinensis Forsius are recorded for the first time from the Indian subcontinent, whereas $N$. manganensis sp.nov. is new to science from this region. With the record of these species, this genus is now represented by twelve species in India.
\end{abstract}

Keywords

New species, first records, Neostromboceros, Hymenoptera, India

\begin{abstract}
EL - eye length
ICD - inter cenchri distance

ITD - inter tegular distance

MB - metabasitarsus

OCL - ocellooccipital line

POL - postocellar line
\end{abstract}

\section{Introduction}

Rohwer (1912) erected the genus Neostromboceros with Stromboceros metallica as its type species from Singapore. There are nine species already on record from Indian zoogeographic limits. Of these, six are described by Cameron $(1888,1899,1902,1907)$ viz., N. rothneyi, N. caeruleiceps, $N$. fuscinervis, $N$. pilicornis, $N$. trifoveatus and $N$. basilineatus, while two, N. indobirmanus and N. speciosus, by Malaise (1944) and one, N. laevis, by Konow (1898). Two species -- N. rugifrons Malaise (1944) and N. tonkinensis Forsius (1931) -- are recorded for the first time from the Indian region. The present text deals with the systematic description and illustrations of a new species along with the redescription of the two newly recorded species. To authenticate their status, each of them has thoroughly been compared with its closely related species. A special attention has been paid to study the population variations and sexual dimorphism.
The types and paratypes will be deposited in the Pusa National Collection, Division of Entomology, Indian Agricultural Research Institute, New Delhi, India, after this work is published. The terminology used in the text is after Ross $(1937,1945)$ and Malaise (1945).

\section{Neostromboceros manganensis sp. nov.}

(Figs. 1-5)

\section{Material examined}

Holotype: Female, 17.v.1985, Mangan, Sikkim, 1800m, Coll. M.S. Saini.

Paratypes: 16 females, 14 males, 12.v.1985, Gangtok, Sikkim, 1700m, Coll. M.S. Saini; six females, five males, 5.v.1995, Phodang, Sikkim, 1500m, Coll. V. Vasu; five males, 7.v.1995, Singtam, Sikkim, 900m, Coll. T.P. Saini; eight males, 4.v.1995, Singtam, Sikkim, 900m, Coll.T.P. Saini; six females, 5.v.1995, Singtam, Sikkim, 900m, Coll. V. Vasu. 


\section{Distribution}

India: Mangan, Gangtok, Phodang, Singtam in Sikkim.

\section{Etymology}

The species name is after its type locality.

\section{Diagnostic features}

Female: Colour, body black, pale whitish are: labrum; extreme apex of scape dorsally; upper pronotal angles; parapterum; last two tergites; posterior margin of apex of coxae; trochanters along with their adjoining parts of femora; apices of femora; longitudinal stripe on outersides of pro and mesotibiae and $2 / 3$ proximal end of metatibia; tarsal segments of pro and mesoleg are lightly yellowish-brown. Yellow are: posterior margin of first tergite; tergites 2-4 and sternites 1-3 entirely and anterior margin of fourth sternite. Wings hyaline, slightly brownish; costa, stigma and venation dark brown.

Structure: Average length 12mm. 4-8 segments of antenna distinctly compressed, $1.75 \mathrm{x}$ headwidth, scape longer than pedicel, pedicel disc shaped and as long as its apical width; segment 3 longer than 4 as 7:6. Anterior margin of clypeus truncate, medial tooth faintly indicated (Fig. 1). Labrum broader than long as 2:1 with rounded anterior margin (Fig. 1). Malar space linear. LID:IDMO:EL=3.0:3.5:3.0; OOL:POL:OCL=2.0:1.0:3.5. Frontal area at level of eyes; lateral supraantennal pits, subdivided into twin-pits of unequal size and continuous with one another by a fine furrow. Median fovea in the form of a shallow medial depression forming a narrow furrow towards medial supraantennal pit. Circum-, inter-and postocellar furrows distinct. Lateral furrows deep, excurved, and distinct upto a little more than halfway and then continue as fine seams up to hypothetical posterior margin of head. Postocellar area almost flat, longer than broad as 6:5. Head subparallel behind eyes. Hind orbits short and distinctly faintly converging downwards. Mesoscutellum flat, its appendage not carinated. ITD:ICD 3.5:1.0. Epicnemium subconvex, separated from mesopleuron by a fine furrow. Mesepisternum obtusely raised without carina or acute apex. Subapical tooth of tarsal claw shorter than apical one and a distinct basal lobe present (Fig. 2). Metabasitarsus shorter than all following tarsal joints combined as 6:7, IATS:MB:OATS $=2.0: 5.0: 1.9$. Lancet (Fig. 5) with 10 serrulae.

Sculpture: Head covered with large shallow punctae more densely on and around the frontal area; mesonotum covered with minute and scattered punctae, scutellum with few large and shallow punctae on the posterior slope; mesopleuron finely and densely punctured along the anterior aspects. Abdomen shining and impunctate.

Pubescence: Body covered with sparse, auratus pubescence.
1
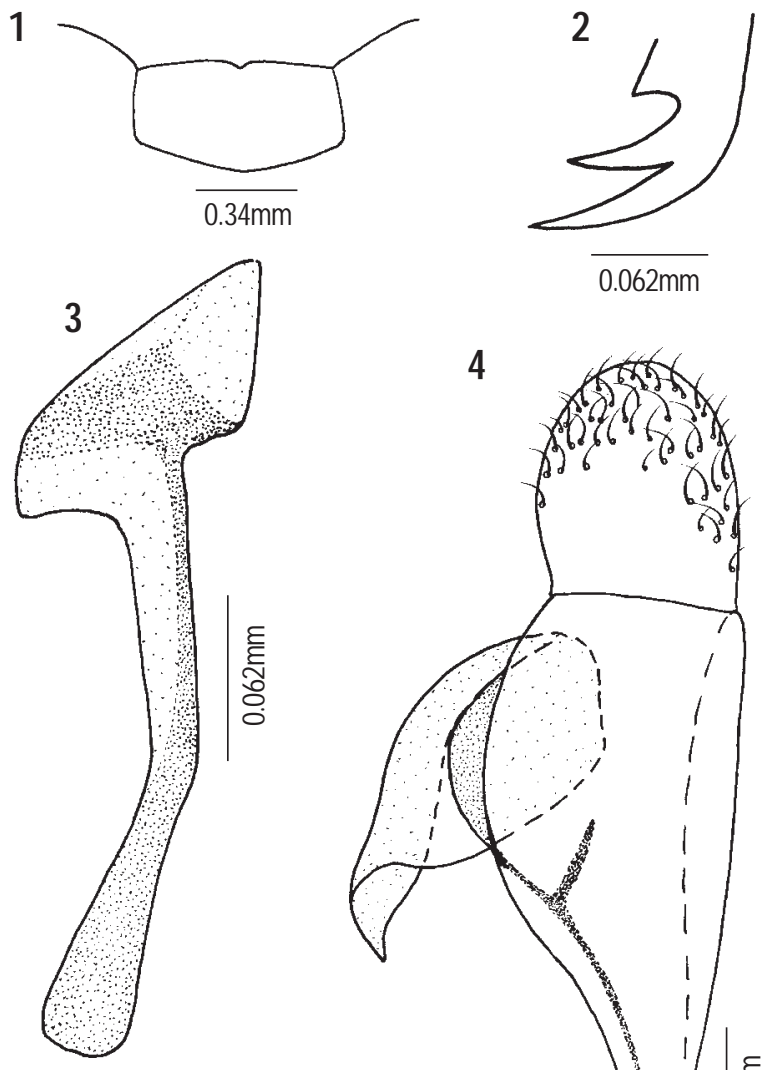

$0.062 \mathrm{~mm}$

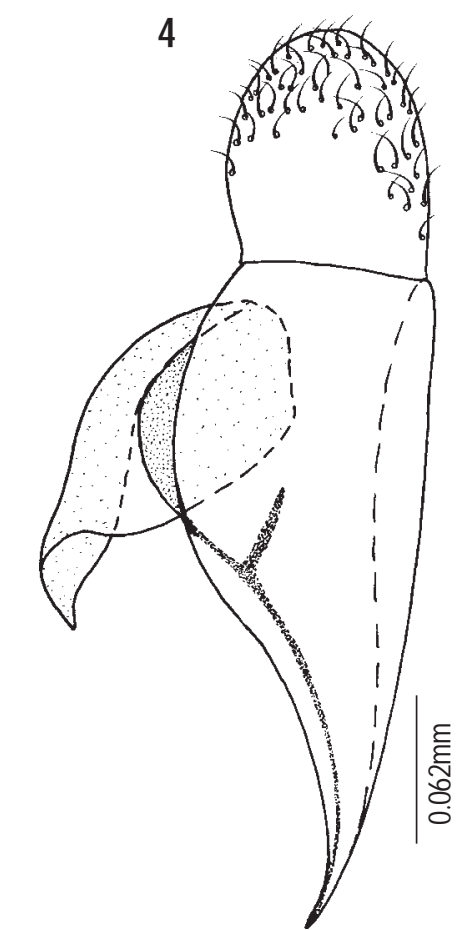

5

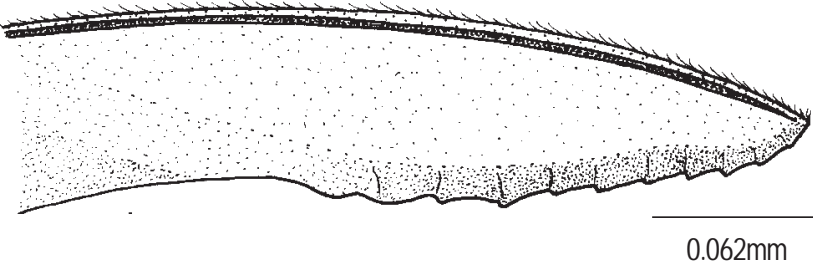

Figures 1-5. Neostromboceros manganensis sp. nov. 1 - Clypeus and Labrum; 2 - Tarsal claw; 3 - Penis valve; 4 - Gonoforceps; 5 - Lancet

Male: Average length $9 \mathrm{~mm}$. Similar to female except for following differences: abdominal tergites and sternites 1-6 yellow (1-4 in female); inner margins of eyes distinctly converging downwards. Genitalia: Penis valve (Fig. 3), Gonoforceps (Fig 4).

Population variation: Yellow coloured abdominal segments are fulvous in some specimens. 


\section{Diagnostic features}

While running in Mataise's 1944 key to the Oriental species of this genus, $N$. manganensis comes close to $N$. pilicornis (Cameron) from which it can be separated on the basis of following characters: head covered with large shallow punctures more densely on and around the frontal area (smooth and shining in pilicornis); antennal segment 3 and 4 as 7:6 (as 5:4 in pilicornis); forewing hyaline entirely (forewing with strongly infuscated apices in pilicornis), and subapical tooth of tarsal claw shorter than apical one (subapical tooth of tarsal claw longer than apicai one in pilicornis).

\section{Neostromboceros rugifrons Malaise (1944) (Figs. 6-10)}

Specimens: One female, five males, 19.ix.1991, Dirang, Arunachal Pradesh, 1500m, Coll. V. Vasu; one male, 23.v.1993, Sessa, Arunachal Pradesh, 1100m, Coll. V. Vasu; two males, 26.vi.1994, Chail, Himachal Pradesh, 2350m, Coll. T.P. Saini; three females, two males, 27.vi.1990, Ghiaghi, Himachal Pradesh, 1880m, Coll. M.S. Saini; two females, two males, 24.vi.1990, Jibhi, Himachal Pradesh, 2500m, Coll. M.S. Saini; two females, 41 males, 1213.vi.1991, Jibhi, Himachal Pradesh, 2500m, Coll. V. Vasu; 34 females, 32 males, 25-28.vii.1982, Kalatop, Himachal Pradesh, 2400m, Coll. M.S. Saini; four females, two males, 14.vi.1984, Kalatop, Himachal Pradesh, Coll. M.S. Saini; two females, three males, 11.vii.1991, Kalatop, Himachal Pradesh, Coll. V. Vasu; two males, 31.v.1983, Kasol, Himachal Pradesh, 1600m, Coll. M.S. Saini; one female, four males, 26.vi.1990, Kasol, Himachal Pradesh, 1600m, Coll. M.S. Saini; four females, 20 males, 29.vi.1993, Kasol, Himachal Pradesh, 1600m, Coll. V. Vasu; two males, 1.v.1984, Narkanda, Himachal Pradesh, 2300m, Coll. M.S. Saini; one female, 14 males, 26.v.1989, Cheerapunji, Meghalaya, 1500m, Coll. M.S. Saini; two females, two males, 12.v.1985, Gangtok, Sikkim, 1700m, Coll. M.S. Saini; 12 females, five males, 17.v.1985, Mangan, Sikkim, 1800m, Coll. M.S. Saini; one female, three males, 11.v.1985, Ranipool, Sikkim, 1400m, Coll. M.S. Saini; 10 females, 22 males, 14.v.1885, Singhik, Sikkim, 1500m, Coll. M.S. Saini; three females, two males, 20.vi.1992, Barkot, Uttar Pradesh, 1800m, Coll. V. Vasu; two females, one male, 23.vi.1991, Chokori, Uttar Pradesh, 2000m, Coll. V. Vasu; one female, two males, 19.vi.1987, Chopta, Uttar Pradesh, 3000m, Coll. M.S. Saini; two females, 1 male, 25.vi.1992, Chopta, Uttar Pradesh, 3000m, Coll. T. P. Saini; five females, three males, 15.vi.1994, Chopta, Uttar Pradesh, 3000m, Coll. T.P Saini; eight females, 18 males, 1314.vi.1994, Fata, Uttar Pradesh, 1700m, Coll. V. Vasu; five females, three males, 18.vi.1983, Gobindghat, Uttar Pradesh, 1500m, Coll. M.S. Saini; one female, four males, 5.vi.1983, Hanuman Chatti, Uttar Pradesh, 2200m, Coll. M.S. Saini; one female, three males, 22.vi.1992, Kuthnaur, Uttar Pradesh, 1500m, Coll. T.P. Saini; 25 females, 57 males, 15.vi.1983, Mandal, Uttar Pradesh, 2200m, Coll.
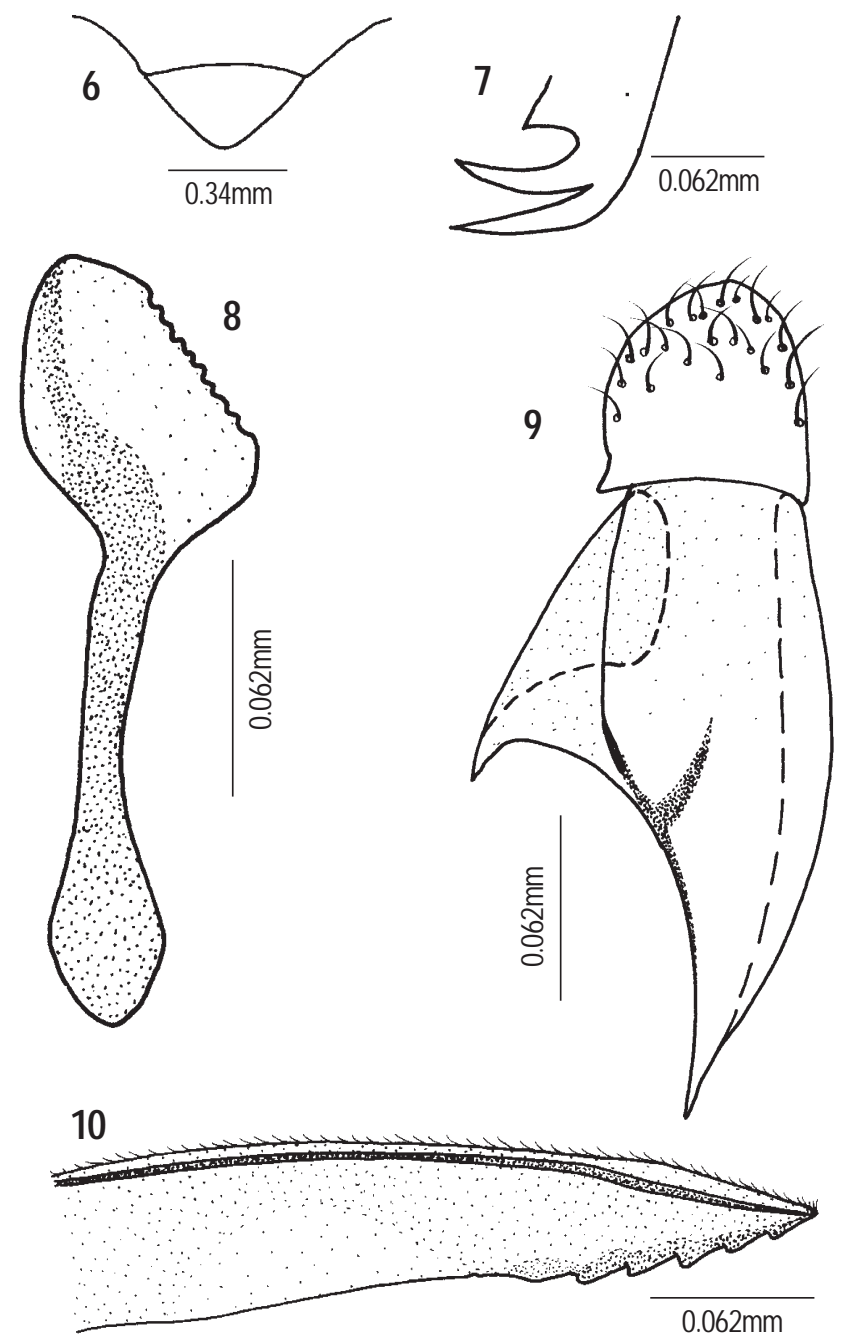

Figures 6-10. Neostromboceros rugifrons Malaise (1944) 6 - Clypeus and Labrum; 7 - Tarsal claw; 8 - Penis valve; 9 - Gonoforceps; 10 - Lancet

M.S. Saini; five females, eight males, 15.vi.1987, Mandal, Uttar Pradesh, 2200m, Coll. M.S. Saini; two females, 21 males, 19.vi.19871, Mandal, Uttar Pradesh, 2200m, Coll. M.S. Saini; three females, four males, 28.v.1989, Mandal, Uttar Pradesh, 2200m, Coll. M.S. Saini; two females, two males, 17.vi.1994, Mandal, Uttar Pradesh, 2200m, Coll. V. Vasu; two females, three males, 24-25.vi.1992, Mastura, Uttar Pradesh, 1800m, Coll. P. Saini; five males, 20.vi.1993, Munsyari, Uttar Pradesh, 2300m, Coll. V. Vasu; five females, five males, 1.ix.1987, Ranikhet, Uttar Pradesh, Coll. V. Vasu; one female, one male, 14.vi.1994, Sonparyag, Uttar Pradesh, 1700m, Coll. V. Vasu; four females, one male, 8.v.1983, Darjeeling, West Bengal, 2300m, Coll. M.S. Saini. 


\section{Distribution}

Myanmar; India: Dirang, Sessa in Arunachal Pradesh; Chail, Ghiaghi, Jibhi, Kalatop, Kasol, Narkanda in Himachal Pradesh; Cheerapunji in Meghalaya; Gangtok, Mangan, Ranipool, Singhik in Sikkim; Barkot, Chokori, Chopta, Fata, Gobindghat, Hanuman Chatti, Kuthnaur, Mandal, Mastura, Munsyari, Ranikhet, Sonparyag in Uttar Pradesh; Darjeeling in West Bengal.

\section{Diagnostic features}

Female: Colour, body black, pale whitish are: extreme apices of meso-and metacoxae: mesotrochanter more or less and metatrochanter entirely with adjoining parts of metafemur, extreme outer sides of proximal end of pro- and mesotibiae, 1/3 proximal end of metatibia; inner sides of basitarsi. sordid yellow. Wings hyaline, forewing slightly infuscated at apex; costa, stigma and venation dark brown to black.

Structure: Average length $8 \mathrm{~mm}$. Antenna incrassate in middle, pointed at apex, $2 \mathrm{x}$ head width; scape longer than pedicel, both are longer than their apical widths; segment 3 longer than 4 as 8:7. Anterior margin of clypeus almost truncate (Fig. 6). Labrum broader than long as 2:1 with accuminate anterior margin (Fig. 6). Malar space linear. LID:IDMO:EL 2.0:2..5:2.0; OOL:POL:OCL $=2 \cdot 2: 1 \cdot 0: 3.0$, Frontal area sligthly below level of eyes. Lateral supraantennal pits subdivided into twin-pits and connected by fine furrow. Frontal depression surrounded by indistinct and blunt frontal ridges. Supraantennal tubercles indicated but not,connected with frontal ridges. Circum- and interocellar furrows distinct, postocellar furrow indistinct. Lateral furrows deep, sharp, excurved (bulging in middle), gradually diminishing backwards and abruptly ending a little more than half-way from hypothetical hind margin of head. Postocellar area subconvex, as long as broad; head narrowing behind eyes. Hind orbits distinctly carinated. Inner margins of eyes subparallel in middle, converging downwards. Mesoscutellum subconvex, its appendage not carinate. ITD:ICD 2.0:5.8:1.8. Lancet (Fig. 10) with five serrulae.

Sculpture: Head profusely and irregularly wrinkled and grooved on and around frontal area, clypeus with large, dense and distinct punctures, and distance between punctures less than diameter of a puncture; labrum and base of mandibles with some large, distinct and scattered punctures, rest of head smooth and impunctate, surface shining. Mesonotum, mesopleuron and mesosternum shining, with minute scattered punctures; mesoscutellum bears large distinct punctures, surface shining. Abdomen impunctate, subshining.

Pubescence: Body covered with dense, brownish golden pubescence.

Male: Average length $7.5 \mathrm{~mm}$. Similar to female except following differences: mesotrochanter black, yellow are: apex of pro- and mesofemora, stripe on outer side of pro- and mesotibiae, metatibia and metabasitarsus entirely. Inner margins of eyes distinctly converging downwards. Genitalia: Penis valve (Fig. 8), gonoforceps (Fig. 9).

Depository: Holotype: Female, N R, Stockholm; paratypes: one male, five females, N R, Stockholm.

Population variation: Some specimens have distinctly compressed antennae.

\section{Remarks}

$N$. rugifrons and $N$. rothneyi closely resemble each other but can be separated on the basis of following combination of characters: lateral furrows of postocellar area sharp but gradually diminishing backwards and reaching hypothetical hind margin of head; and without distinguishable furrows or carinae between lateral furrows directed forward from median ocellus (lateral furrows sharp, deep, hardly diminishing backwards and abruptly ending a little more than half-way from the hind margin of head; and a carina between lateral furrows directed forward from median ocellus in $N$. rothneyi). N. rugifrons was described by Malaise (1944) from Burma. This species is reported for the first time from India. The specimens dealt here with agree earlier descriptions of this species.

\section{Neostromboceros tonkinensis Forsius (1931)}

(Figs. 11-13)

Neostromboceros tonkinensis Forsius, 1931:35-36; Malaise 1944: 39

\section{Material examined}

Specimens: One female, 19.v.1992, Jorumtop,Arunachal Pradesh, 2200m, Coll. T.P. Saini; one female, 26.vi.1991, Gini, Uttar Pradesh, 2050m, Coll. V. Vasu; one female, 15.vi.1984, Chopta, Uttar Pradesh, 3000m, Coll. M.S. Saini; one female, 5.v.1985, Mandal, Uttar Pradesh, 2200m, Coll. M.S. Saini.

\section{Distribution}

Tonkin; India: Jorumtop in Arunachal Pradesh; Gini, Chopta, Mandal in Uttar Pradesh.

\section{Diagnostic features}

Female: Colour, body coal black, pale whitish are; labrum; clypeus except base; broad upper pronotal margin; tegula; parapterum; all legs except piceous extreme bases of coxae and apical two tarsal segments. Wings hyaline, costa, stigma and venation light to dark brown.

Structure: Average length $7 \mathrm{~mm}$. Antenna filiform, 1.6x head width, scape longer than pedicel, both are longer than their apical widths; segment 3 longer than 4 as 4:3. Anterior margin of clypeus shallowly arcuately emarginate up to $1 / 6$ th of its medial length 
(Fig. 11). Labrum broader than long as 2:1 with rounded anterior margin (Fig. 3). Malar space linear. LID:IDMO:EL= 2.0:2.5:2.4: OOL:POL:OCL $=1.2: 1.0: 1.4$. Frontal area raised to level of eyes and indistinct. Median and lateral supraantennal pits distinct but lateral supraantennal pits not divided into twin-pits; median fovea in the form of shallow medial depression. Supraantennal tubercles and frontal ridges insignificant. Circum- and interocellar furrows distinct, while postocellar furrow absent. Lateral furrows distinct, diverging backwards and abruptly ending just before reaching halfway to hypothetical hind margin of head. Postocellar area faintly tectiformly convex, broader than long as 4:3. Head narrowing behind eyes. Hind orbits carinate at base of mandibles. Inner margins of eyes subparallel in the middle and converging downwards. Mesoscutellum subconvex, its appendage not carinate. ITD:ICD 3.5:1.0. Epicnemium subconvex, separated from mesopleuron by almost distinct furrow. Mesepisternum obtusely raised without carina or acute apex, tarsal claw with subapical tooth shorter than apical one (Fig. 12). Basal lobe distinct. Metabasitarsus equal to following tarsal joints combined. IATS:MB:OATS = 2.0:5.0:1.7. Lancet (Fig. 13) with six serrulae.

Sculpture: Head and thorax impunctate except posterior slope of mesoscutellum that bears 4-5 large shallow punctures in a row, surface smooth and shining. Abdomen impunctate, subshining.

Pubescence: Body covered with silvery, almost negligible pubescence.

Male: Not known.

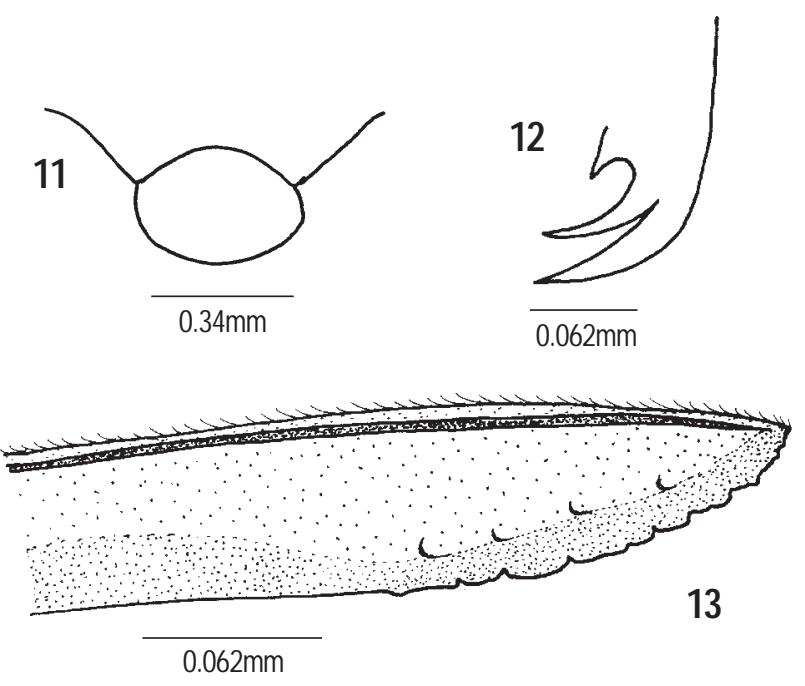

Figures 11-13. Neostromboceros tonkinensis Forsius (1931) 11 - Clypeus and Labrum; 12 - Tarsal claw; 13 - Lancet
Depository: Holotype untraceable.

Population variation: All specimens are alike.

\section{Remarks}

Neostromboceros tonkinensis was described by Forsius (1931) from Tonkin. The material dealt with here agree well with the earlier descriptions of the species. This species is reported for the first time from India. This species quite closely resembles $N$. indobirmanus but can be separated from it on the basis of the following characters: postocellar area broader than long as 3:2 (5:4 in indobirmanus); clypeus arcuately emarginate (triangularly emarginate in indobirmanus), and wings hyaline (apical half of front wings somewhat infumated in indobirmanus).

\section{Acknowledgements}

The authors are deeply indebted to Dr. D.R. Smith of U.S. Department of Agriculture, Washington, D.C., for his valuable suggestions. We are also highly thankful to U.S. Department of Agriculture, Washington for financing the PL-480 Project in, collaboration with the Indian Council for Agriculture Research, New Delhi, India, under which this work was carried out.

\section{References}

Cameron, P. (1888). Descriptions of twenty three new species of Hymenoptera. Memoirs and Proceedings of the Manchester Literary Philosophical Society 4(1): 159-183.

Cameron, P. (1899). Hymenoptera Orientalia, or contributions to a knowledge of Hymenoptera of the Oriental Zoological Region, Part VIII. The Hymenoptera of Khasia Hills. First paper. Memoirs and Proceedings of the Manchester Literary Philosophical Society 43(3): 1-50. Cameron, P. (1902). Descriptions of new genera and species of Hymenoptera, collected by Maj. C.S. Nurse at Dessa, Firozpur and Shimla, Part 1. Journal of the Bombay Natural History Society 14: 433-447.

Cameron, P. (1907). On some undescribed phytophagous and Parasitic Hymenoptera from the Oriental Zoological region. The Annals and Magazine of Natural History, London 7(19): 166-192.

Forsius, R. (1931). Ueber einige neue order wening bekannte orientische Tenthredinoiden. The Annals and Magazine of Natural History, Wien 46: 29-48.

Konow, F.W. (1898). New Chalastogastra - Gattungen und Arten. Entomologische Nachrichten 24(17): 268-282.

Malaise, R. (1944). Entomological results from the Swedish expedition 1934 to Burma and British India. Arkiv fur Zoologie 35A(10): 1-58. Malaise, R. (1945). Tenthredinoidea of South-eastern Asia with a general Zoogeographical review. Opuscula Entomologica Supplementum 4: 1-288.

Rohwer, S.A. (1912). Notes on sawflies with description of new species, Washington D.C. Smithsonian Institute. Proceedings of the U.S. Natural Museum 43: 205-251.

Ross, H.H. (1937). A generic classification of the Nearctic sawfiies (Hymenoptera:Symphyta) Ill. Biological Monograph, 34: 1-173.

Ross, H.H. (1945). Sawfly genitalia: Terminology and Study Techniques. Entomological News 56: 261-268. 